committees and also conducted the Arctic Sea Ice Conference in February 1958 at the request of the Government. The Division of Engineering and Industrial Research provided advisory services over a wide field of increasing importance and complexities, including such matters as electrical insulation, fire research, highway research, building research, prosthetics research. The Division of Mathematics appointed two new committees, one on statistics and the other to report both to the Division and to the Advisory Board on Education, on mathematical films and television. The Division of Medical Sciences initiated a new project in medical genetics, which will establish a large roster of veteran twins, diagnosed as to zygosity, as well as other studies of rheumatoid arthritis, lesions of the lumbar disk and Japanose $B$ encephalitis. The interest of the Sub-committee on Trauma continued to centre on the treatment of burns, particularly those involving the respiratory tract. The Division also participated in the establishment of the Interdepartmental Committee on Blood Programme Research and through its Committee on Sanitary Engineering and Environment the Division is in- creasingly concerned with toxicological hazards arising from the rapid introduction of many new types of material into industry and into the home. The Committee on Tissue Transplantation sponsored a symposium on serological immaturity and agammaglobulinæmia and non-specific forms of lowered resistance to transplanted tissues, including the effects of radiation and cortisone. A primary aim of a revised programme of the Committee for Research into the Problems of Sex is the encouragement of young investigators interested in careers in the field of behavioural research.

The Division of Physical Sciences reports a balance between activities in response to requests from the scientific community and in response to Government requests and between those in physical science and in applied science. Its Committee on Nuclear Science continued to be the largest and most active. Its services to the Government included those of the Committee on Undersea Warfare and the Mine Advisory Committee, and the critical review of Air Force research and development planning noted above and a review of the activities of the National Bureau of Standards.

\title{
CLERICAL SALARIES IN BRITAIN
}

$\mathrm{T}$ 'HE eighth of the Office Management Association's surveys of clerical salaries embraced a sample of almost ninety thousand clerks*. For the most part, these were employed in private commercial, industrial and professional offices. In addition, one part of the survey related to clerks employed in the public service, nationalized industries, and the joint stock banks. In one form or the other, therefore, the survey supplied information about the salaries of clerks in all parts of the British economy.

Women clerks formed 64 per cent of the clerks in the sample. This compares with the 67 per cent of women among the clerks employed in the corresponding industries in 1951 when the last census of population was taken.

The clerks were employed in a wide variety of British industries but some industries were better represented in the sample than others: ceramics, glass and cement, etc. ; chemicals and allied trades ; metal manufacture; engineering, shipbuilding, and electrical goods ; textiles ; food, drink and tobaceo; other manufacturing industries were well represented by samples amounting to 10 per cent or more of the clerks employed in industry. The very large number of clerks employed in vehicle manufacture, distributive trades, and in professional and miscellaneous services, were represented by samples of less than 5 per cent. There had been no change since earlier surveys in the proportion of clerks employed on work of this kind. For the men this proportion was only 60 per cent; but 83 per cent of the women were in routine jobs.

On the whole, male clerks' salaries have risen between 12 and 16 per cent in the past two years and those of women clerks between 11 and 13 per cent. The exceptions to this pattern are male clerks doing the lowest grades of routine jobs, whose salaries have risen by between 16 and 27 per cent, and the women doing the lowest grade of routine

* Clerical Salaries Analysis, 1958. (Office Management Association, 58 Victoria Street, London, S.W.1.) 428 . jobs, whose salaries have risen by 14 per cent (clerks under twenty years) and 17 per cent (clerks over twenty years). As the index number of retail prices has risen by 7 per cent during the same period, the real salaries of the clerks have gone up between nearly 5-9 per cent for men and 4-6 per cent for women. Superimposed on this general increase is a large rise for clerks doing the lowest routine jobs.

Manual workers' wage rates during the period from February 28, 1956, to the same date in 1958 rose by just over 11 per cent. Clerical salaries, therefore, rose as much as, or more than, the wage rates of manual workers during the past two years. Wage rates do not, however, tell the whole story concerning manual workers' share of the national economic cake; the fluctuations in their earnings may differ quite considerably from the fluctuations in wage rates. No similar complication affects clerical salaries to anything like the same extent.

It appears, nevertheless, that clerks have in this period done rather better than manual workers in the continuous process of redistributing income. This comes after a decade in which male clerks have been losing ground to manual workers.

Increases have been proportionately less for clerks engaged on more senior and responsible work. Many have scarcely had any increase in salaries at all over and above that accounted for by the fall in the value of money. Because the salary increases during the past two years have been proportionately slightly less for women than for men, the gap between the salaries of men and women clerks doing similar work has widened a little since 1956.

The United Kingdom does not form a single market for clerical labour and even nation-wide employers of clerks recognize this, at least to the extent of introducing London allowances into their national scale. These scales and allowances may be administratively convenient, but the pattern of local clerical markets is more complex than the simple one of a London market and a provincial market assumed by 
most national employers. The areas of the highest salaries were mainly those having the prosperous engineering, shipbuilding, food-processing and chemical industries in good measure with a high proportion of export trade. It is reasonable to assume that the pattern of clerical salaries for adult male clerks followed a pattern of economic prosperity.

London comes fairly low down on the scale. Within Greater London there was only one district-the West End-where salaries were comparable with those on Merseyside. This is in contrast with the usual assumption that salaries are generally higher in London than in the rest of the country.

The pattern of variations of salaries for women clerks is simpler and more in accordance with traditional ideas. Greater London was the area of high salaries; the other conurbations had noticeably lower salaries with little to choose between them in contrast with the experience of men clerks in this area.

\title{
HELP FOR THE ARTS
}

$\mathbf{A}^{\mathrm{L}}$ LTHOUGH the full policy of the Calouste Gulbenkian Foundation of Lisbon includes the fields of science, art, education and charity, it now announces that it is prepared to implement the suggestions in a report just issued*. This means that for the next three or four years the emphasis of the activities of the Foundation in the United Kingdom will be almost exclusively in the field of the arts.

The report, prepared by a small informal committee consisting of Lord Bridges (chairman), the Countess of Albemarle, Mr. Nöel Annan and Sir George Barnes, is the result of their deliberations to help the Foundation by a review of the needs of the arts in Britain. After a few discussions in London the committee visited Bristol, Cardiff, Glasgow, Liverpool, Newcastle upon Tyne and Nottingham. Information was also supplied by a hundred local authorities and by all the universities.

Probably the most striking and indeed definite conclusion is that the arts need help in the provinces to a far greater extent than they do in London. Another point is that far greater support is needed for the arts than in the past and also that this is not a temporary need. This means that in the future public authorities will have to find more money for the arts. It is also stressed that far more needs to be done to-day to render the arts accessible, that there should be more scope for experiment in order to invigorate the arts and that more should be done to foster appreciation among the young. If as the committee believes, the Foundation can do its best service by stimulating art in the provinces it is pointed out that although under the Local Government Act of 1948 local authorities are permitted to spend up to a $6 d$. rate each year on any form of entertainment it is

* Help for the Arts : a Report to the Calouste Gulbenkian Foundation. Pp. 64. (London: Calouste Gulbenkian Foundation, United Kingdom and British Commonwealth Branch, 1959.) $3 s$. ascertained that over the whole country expenditure does not exceed $\frac{3}{4} d$. rate for museums and art galleries and $\frac{1}{5} d$. for music and drama. The members of this informal committee consider that the universities could and should do much more for the 'practice' and encouragement of the arts. Traditionally, this has been left to university societies and thus is outside the scope of the university patronage.

In discussing the specific ways in which the Foundation can help, it is stressed that it should be prepared to back individuals-and to encourage and foster new developments or growing points, feeling that eventually they will be self-supporting and attract permanent support from public funds or elsewhere.

Museums and art galleries receive much considera. tion, and although the committee welcomes the in. crease in grants recently announced it is suggested that pictures accepted by the Treasury in lieu of death duties should in certain cases pass to the provincial galleries. This involves the acceptance of pictures perhaps not of exceptional importance but of great interest to a local gallery. It is also felt that although museums have done much good work in developing school services they seem to have lagged behind the expension in other educational fields. A more active policy of loans between museums is advocated, and for this a general survey of material in the collections is essential. This also leads to the establishment of an improved conservation service. It is also suggested that the Foundation might help to buy works of art for provincial galleries.

In conclusion, the committee considers that Great Britain is producing artists of the highest quality, but adequate support or patronage is lacking. It is to be hoped that the Foundation gives a speedy implementation to the suggestions in this report and then in good time turns to the support of the sciences in Great Britain.

\section{DIETARY FACTORS IN THE HOMOGRAFT REACTION}

\author{
BY Dr. A. S. PARKES, F.R.S. \\ Division of Experimental Biology, National Institute for Medical Research, Mill Hill, London, N.W.7
}

$\mathrm{E}$ XPERIMENTS carried out in 1955 with five strains of mice maintained at this Institute showed that ovarian autografts established themselves regularly and became endocrinologically active within an average time of 10-11 days. In three of the strains intra-strain homografts behaved similarly during the four-week period of observation. In the other two strains, intra-strain ovarian homografts took and survived less well than autografts. Inter-strain ovarian grafts took moderately in some combinations, but rarely survived for four weeks ${ }^{1}$.

Repetition of some of these experiments two years later showed that there had been a marked increase in resistance to intra-strain grafts. In the three 